\title{
Horshoe Kidney Transplantation: The First Case in Our Hospital
}

\author{
Gomis Goti C*, Quicios Dorado C, Cabello Benavente R, Alcoba Garcia MP, Martinez Mateo MA, Garcia \\ Fernindez E and Gonzalez Enguita C \\ Department of Urology, Fundacion Jimenez Diaz Universitary Hospital, Spain
}

Submission: January 17, 2017; Published: February 28, 2017

*Corresponding author: Gomis Goti C, Department of Urology, Fundacion Jimenez Diaz Universitary Hospital, Spain, Tel: 91-550 48 00; Email: carmen.gomis@fjd.es

\begin{abstract}
Although the rate of donors per million inhabitants is comparatively high in Spain, there remains an imbalance between the number of donors and patients awaiting kidney transplantation. This discrepancy has led urologists to consider new sources for transplantation, including kidneys with atypical anatomy such as horshoe kidneys. We report the first horshoe kidney transplantation in our hospital and its short-term outcome. Horshoe kidney transplantation poses a surgical challenge for the urologist, although the positive outcomes obtained here and as reported in the literature make a strong case for horshoe kidneys to be considered by expert surgeons as another source for kidney transplantation.
\end{abstract}

Keywords: Transplant; Kidney; End stage renal disease; Horseshoe kidney

Abbreviations: ESRD: End-Stage Renal Disease; HSK: Horshoe Kidney

\section{Introduction}

In Spain, 8-10\% of patients with end-stage renal disease (ESRD) die while they are waiting for a compatible organ for transplantation [1]. The number of patients with ESRD on the transplantation waiting list has increased in recent years, while the number of cadaver donors has decreased [1]. This discrepancy has led urologists to consider kidneys with atypical anatomy as a viable source for transplantation [2].

Horshoe kidney (HSK) is a fusion anomaly found in approximately 1 in $400-600$ people [3]. HSK is frequently associated with other congenital malformations, though patients usually have normal renal function [4]. Cases of HSK have complex vascular anatomy sometimes associated with abnormalities in the upper urinary tract [3]. Therefore, urinary tract infections, vesicoureteral reflux, nephrolithiasis, and hydronephrosis are frequent complications in these patients.

\section{Case Report}

The recipient was a 74-year-old male with ESRD caused by hepatorenal polycystic disease. He had been in hemodialysis since January 2015, and as concomitant pathology the patient was a heterozygous carrier of the C677T mutation of the MTHFR gene, though he had not experienced any thromboembolic events.
The graft was an HSK obtained from a 79-year-old diabetic donor who was brain dead at the time of harvest. Each half of the HSK had one single renal vein and principal artery and an upper and lower polar artery. During back-table surgery, the isthmus was transected with a metal linear stapler. The main renal artery and upper polar artery were preserved in each half and both lower polar arteries were sacrificed due their proximity to the renal isthmus and for purposes of vascularization. The right half of the HSK was transplanted, though the left half was rejected due to compromised vascularization after it was detected that the lower polar artery was irrigating only $50 \%$ of the volume of this half.

The transplantation site was the right iliac fossa. Vascular anastomosis between the renal vein and right external iliac vein, the renal main artery and right common iliac artery, and polar artery and iliac external artery was carried out. Cold ischemic time was 19 hours. Lich-Gregoir ureteroneo cystostomy was performed, inserting a JJ catheter and suturing was done with 4/0 absorbable monofilament polydiaxanone sutures.

Following our center's protocol, a Doppler ultrasound scan was performed $48 \mathrm{~h}$ after transplantation, revealing a resistive index of 0.8 , good graft perfusion, and no signs of renal vein 
thrombosis. On the fourth day after transplantation, renal scintigraphy (Figure 1) was performed, showing a moderate decrease in the vascular and deposit phases of the graft, presenting atypical morphology (HSK), hypo perfusion in the lower pole, and retardation of the excretion phase. These findings are compatible with moderate acute tubular necrosis and compromised irrigation of the lower pole following section of the lower polar artery.

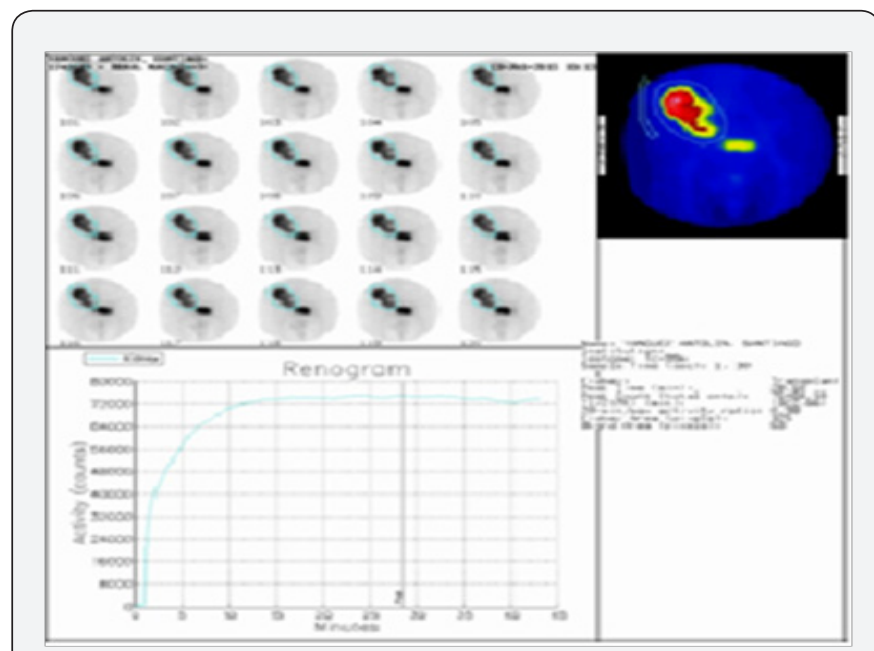

Figure 1: Fourth day after transplantation, renal scintigraphy.

In the immediate postoperative period, the patient had delayed graft function, requiring 2 hemodialysis sessions. Creatinine levels at discharge were $2.7 \mathrm{mg} / \mathrm{dL}$, and he remained stable, at 3 months, at $2.5 \mathrm{mg} / \mathrm{dL}$.

An ultrasound scan was performed 1 month after transplantation due to a urine infection with impaired kidney function, showing moderate hydronephrosis in the graft. Antegrade pyelography (Figure 2) was performed, after which ureteroneocystostomy stenosis was ruled out as the cause of obstructive uropathy.

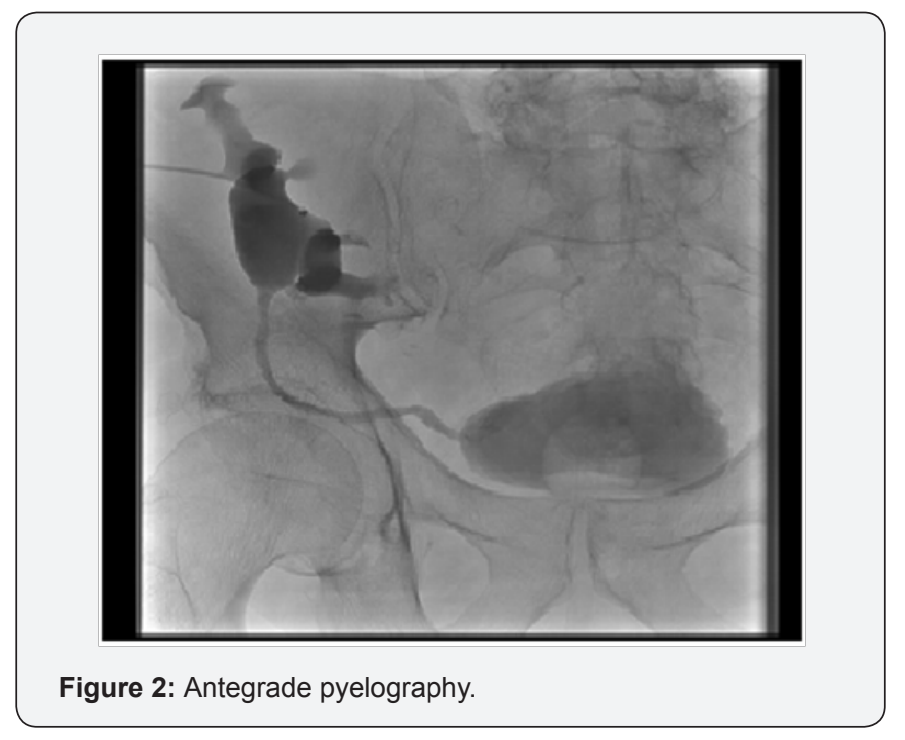

\section{Discussion}

Da Carpi was the first to report a case of HSK, doing so in 1552 [5]. In 1963 the first HSK transplantation was carried out by Politano; he successfully implanted the right half of an HSK from the recipient's monozygotic twin, although the results were not published. In 1975, Nelson et al. published the first report of HSK transplantation [6].

Anatomical variations of HSK may cause greater technical difficulties when performing kidney transplantation, possibly causing urologists to reject these organs for transplantation. HSK transplantation can be done en bloc or in split fashion, depending on the available anatomical space and vascular and urinary tract anatomy. The number of arteries and veins present in HSK are not correlated with delayed graft function. Nevertheless, a $9 \%$ difference has been seen in the rate of delayed graft function between en bloc transplantation and sectioning through the isthmus [7]. Successful living-donor transplantations of kidneys with horseshoe malformation have been reported $[8,9]$.

HSK transplantation is a surgical challenge for the urologist due to anatomical complexity, although this should not be cause to eliminate these organs as potential kidney transplantation grafts.

\section{References}

1. Activity reports of donation and transplantation.

2. Stroosma OB, Scheltinga MRM, Stubenitsky BM, Kootstra G (2000) Horseshoe kidney transplantation: an overview. Clin Transplant 14(6): 515-519.

3. Glodny B, Petersen J, Hofmann KJ, Schenk C, Herwig R, et al. (2009) Kidney fusion anomalies revisited: clinical and radiological analysis of 209 cases of crossed fused ectopia and horseshoe kidney. BJU Int 103(2): 224-235.

4. Glenn JF (1959) Analysis of 51 patients with horseshoe kidney. N Engl J Med 261: 684-687.

5. Da Carpi B, Isagogae breves perlucide ac uberrime in anatomiam humani corporis. National Library of Medicine. Woodcut pp. 1535.

6. Nelson RP, Palmer JM (1975) Use of horseshoe kidney in renal transplantation: technical aspects. Urology 6(3): 357-359.

7. Stoosma OB, Schurink GW, Smiths JM, Kootstra G (2001) Transplanting horshoe kidneys: a worldwide survey. J Urol 166(6): 2039-2042.

8. Goyal A, Gaitonde K, Sagade SN, Shah BV, Kamat MH (2003) Transplantation of horseshoe kidney from living-related donors: report of two cases. Transplant Proc 35(1): 32-34.

9. Hüser N, Geraurer KE, Novotny AR, Assafalg V, Stangl MJ (2005) Successful living donor transplantation of a kidney with horseshoe malformation: extending the donor pool. Transplant Int 18(6): 761762 . 
(C) Comons Attribution 4 This work is licensed under Creative (C) BY Commons Attribution 4.0 License
Your next submission with Juniper Publishers will reach you the below assets

- Quality Editorial service

- Swift Peer Review

- Reprints availability

- E-prints Service

- Manuscript Podcast for convenient understanding

- Global attainment for your research

- Manuscript accessibility in different formats

( Pdf, E-pub, Full Text, Audio)

- Unceasing customer service

Track the below URL for one-step submission https://juniperpublishers.com/online-submission.php 